\title{
HEGEMONIC DISCRIMINATION AS SEEN IN ERNEST J. GAINES' A LESSON BEFORE DYING
}

\author{
Achmad Naufal Irsyadi [1], Itsna Syahadatud Dinurriyah [2]
}
[1] naufalirsyadiachmad@gmail.com, [2] duasyahadat@yahoo.com Fakultas Adab dan Humaniora UIN Sunan Ampel Surabaya Surabaya, Jawa Timur, Indonesia

\begin{abstract}
The progress history of Black Africans in America remains a slice of the history of minority struggle in the world of inferiority. Racism becomes a brand topic in every sector of Blacks live in America. War and act of reformation as ways against racism are almost routinely done by Black Americans to reach their civil rights as Americans. Although the war against racism has ended, but racism atmosphere can still be felt, and it seems to have been felt by Ernest J. Gaines in his novel entitled $A$ Lesson Before Dying. Therefore, this writing would like to analyze and describe hegemonic discrimination by White Americans. Hegemonic discrimination is a new phenomenon for Black Americans in the Southern. This theoretical foundation refers to the theory of Hegemony by Antonio Gramsci that is applied to see how discriminative hegemony is implemented smoothly and comfortably.
\end{abstract}

Keywords: Hegemony; Black American; White American

\section{INTRODUCTION}

The issue and discourse of Black and White people in America have become daily issue since it was voiced when a war against racism had done to these contemporary days. It also becomes regularly key topics to mostly academic reseach and project. The making of these kinds of writing which contain of racism phenomena in mostly selected literary work is to reveal how racism is smoothly and anarchically separating the subordinate group of people by any different ways. Black Americans are main issue in the racism discourse as what narrated in Ernest J. Gaines A Lesson Before Dying.

A Lesson Before Dying is an America novel which is composed by Black American author. This novel attempts to reveal and fully presents the life of black Americans in the Southern. Ernest J. Gaines brings to the novel the same rich sense of place, the same deep understanding of the human psyche, and the same compass for Blacks and their struggle. The author, Ernest J. Gaines, was however one of Black American writers whose works were famous with the life of Black Americans. Ernest J. Gaines was born on January 15, 1933 on the River Lake Plantation nearby New Roads, Pointe Coupee Parish, Louisiana, and grew up there when the Southern society was racially segregated. As a boy, he worked in the plantation fields nearby Baton Rouge, Louisiana. He had been forced to work long hours toiling in the fields, and had arrived in California with just the skimpiest of education (Abrams, 2010:13).

The novel tells about Black Americans life in the Southern who were called as Free Blacks. Free Blacks lived in the Southern, and were treated as second civil. As the novel told, that Black people in the novel had indicated that they had a right to live like other White people. It is proven in the novel that Blacks had been served proportionally by Whites 
who handed a wisdom. They can interact and meet the Whites, getting an education, being on societal participation, owing property, working on plantation, and getting a job as soldier unlike Black Slaves in the North.

Blacks were treated in different way. They were sometimes hanged for minor offense, and judges which sentenced those who accused of minor crimes to slavery. In addition, when a free Black left some states, he or she was not allowed to return to the origin place. Luckily, it was unbelievable that White and free Blacks often did a business one another like harvesting crops, founding churches together, and joining in spousal unions (Hargis and Griffin, 2012:115). It indicated that the free Black in the Southern did not get fully a bad treatment by Whites, but they also had a better life when they interacted with Whites. It is because of their uncertain status in the Southern.

Over all the comfortable life of Blacks as free Blacks in the Southern, a discourse of discrimination can still be identified in the novel. Although free Blacks in the novel experience a sufficient good life, but they are still under the mastery and law of Whites. As the story in the novel runs, Blacks are still restricted by a law. A restriction of law is in the interaction between Blacks and Whites, getting an educational facilities, and rights on societal participation. It is in line with the argument of Freeman (2011:465) who states that free Blacks experienced the restriction of law in educational, economic opportunities, political and legal rights. Thus, these cover how the restriction of law in some previous cases are evidently portrayed.

The discrimination towards Black Americans in the Southern, leads to the discourse of hegemonic discrimination. It means that Black who were treated as in the novel received the treatments done by White Americans within the novel. Hegemonic discrimination is adopted from the theory of hegemony by Italian Marxist, Antonio Gramsci. One of Gramsci's ideas is the concept of ideological domination. It is said that when one ideology dominates, it suppresses any other ways of explaining reality. In his idea, Gramsci adds another dimension of hegemony that is domination by consensus. A consensus contributes equilibrium for the social maintenance (Saifuddin, 2006:326).
This writing is entitled Hegemonic Discrimination as Seen in Ernest J. Gaines' A Lesson Before Dying. It is made to find factual pieces of hegemonic discrimination done by White Americans to Black Americans, and to identify the effect of the hegemony.

\section{Method}

This writing applies descriptive qualitative method. According to Raco (2010:60), the data in descriptive research will concern to text. This research does not take any concern on data counting, but it concerns on the interpretation and analysis on the object with some helps of related literatures.

There are several stages in conducting research to the object and analyze it. The stages are: Reading the novel $A$ Lesson Before Dying by Ernest J. Gaines, Taking a note and understanding the intrinsic element of the novel A Lesson Before Dying by Ernest J. Gaines, Collect some related quotation including dialogue and prologue according to the statement of problem, and analyze the collected quotes from the novel.

\section{Hegemony (The Application of Consensus)}

The theory of hegemony is pioneered by Antonio Gramsci, an outstanding Italian Marxist. The notion of hegemony is illustrated in Gramsci's popular book The Prison Notebooks. The Prison Notebooks was written when Gramsci was in the jail that the Italian Fascist government sentences him to imprison his ideas in which he was not capable to write his ideas. The book which consists of 33 daily notes and 2.848 handwritings contains the ideas of hegemony and civil society (Ratna, 2005:184). Thus, the notions of hegemony are explained in Gramsci's outstanding book The Prison Notebook

In general, hegemony can be construed as an influence of leadership, power, and domination of a social group to another social group (Jackson II and Hogg, 2010:324). It is also a control of one social group to other social group. The control can be manifested in the form of domination and authority in field of social, culture, ideology and economy. It can be precisely stated that hegemony can be performed in the sector of social, culture, ideology and economy, and it is manifested in the term of domination. 
According to Gramsci's thought on hegemony, it is true that hegemony is a power or domination on life values, norm, and culture of social group where the domination will be a doctrine for other social groups, so that the indoctrinated social group will consciously follow. It means that the dominated social group does not have a sense of being oppressed. It is similar as Plehwe, Walpen and Neunhoffer's argumentation in their book that:

“... It combines the aspects of 'political leadership' and 'consensus'. Hegemony is to be understood as the ability of the ruling groups and classes to pursue their interests in such a way that they are regarded as common or general interests by ruled groups and classes, and that there are broadly shared ideas about social relations and their development. To this extent, hegemony is the active consent of the ruled" (2006:246).

According to Gramsci, the most important factor as the stimulant of hegemony is the ideological and political factor which is created by the dominating social group in influencing, directing and shaping the public mindset (Budiman, 2002:127). It means that the dominating social group which performs hegemony is caused by the ideological and political aspect. For the success of performing hegemony and as referring to previous statement clarified by Plehwe, Walpen and Neunhoffer, the dominating social group should give a consensus on their subordination to dominated social group. It is done for the purpose of obtaining a respect of dominated social group. Thus, the previous assumption of Gramsci's hegemony reminds to what is called as dominating by moral leadership and intellectual consensually.

As the practice of consensual hegemony, Patria and Arief (1999:124-126) said that the consensus is seen as a desired action and voluntarily which is accepted individually. It is also known as the starting point of Gramsci's hegemony. Gramsci always relates the term consensus with psychological spontaneity which includes a variety of sociopolitical acceptance of the rule or other rules. For Gramsci, hegemony through consensus emerges through an active commitment on the social class which has historically born in the relations of production. Through a consensus, the ideology of the dominant group can be spread to others.
As Simon (2001:23) says that consensus is a major point in Gramsci's hegemony. Consensus is performed in the way of politic and ideology, but it just remains ideology as a first major focus in the hegemony of Gramsci. Ideology can be identified as a set of ideas which supports a power of particular social group (Barker and Jane, 2016:602). Ideology stands to construct a condition of being tied which maintains a social control practiced through consensual arrangement. Thus, ideology is definable as a set of ideas which is performed by a particular social group to maintain and stabilize the hegemony to other groups.

The above statement indicates the important of ideology in the process of hegemony. It is known that ideology plays an important role in consensual hegemony of Gramsci. It is also a set of ideas and principles that explain how society works, and it offers an extract of order of particular society. It means that it performs a power which eventually produces a consensus of a dominated social group. Therefore, for the dominant class, ideology is aimed of maintaining social cohesion and the dominant interests.

Furthermore, ideology works in the social life of society through two levels: level of philosophy and common sense level. Common sense is the public awareness in the practice of everyday life. According Eriyanto (2001:107), if the idea or the notion of a dominant group is accepted as common sense, and the ideology is accepted, the hegemony has clearly occurred. From this view, it is known that the existence of a procedure for the implementation of hegemony by a social group against other social group, is clearly available. It can be seen that common sense which is known as an ideology of the practice of everyday life, can be accepted by the other groups. Therefore, it can be stated that the success of hegemony will appear as the success of a dominant group by the acceptance of dominated social group over the ideology and common sense which the dominant social group spreads.

There can be summarized that the hegemony of a social group can be performed in several phases which can be formulated as a phase of domination and a phase of direction. A phase of domination is performed 
by a social group which intends to include its idea or thought. It can be said that a phase of domination is the first stage in the process of Gramsci's hegemony. It firstly implants the idea of a social group to other social group. After implanting the idea of a social group, a phase of direction comes to strengthen the implanted idea. It is defined that a phase of direction means a direction performed by a social group to perform domination to dominated social group.

\section{FINDINGS}

In the novel by Ernest J. Gaines, Black Americans who becomes free Blacks in the Southern America get a different life of Blacks in the Northern America, where Black people in the Northern America are still enslaved by Whites. The Black people in the Northern work as farmer who usually plant and harvest crops (Hatt, 2007:22). The life of Black American in the Southern looks like human life in general. They usually interact with White people, visiting to their residence, getting a decent job, and earning the right to life like other people's lives. However, on the sidelines of life and the relationship between Blacks and Whites, there is still a discrimination against Blacks. Some of the laws and restrictions are still enforced. The discrimination is consensually accepted by Black people, because the life they have in the Southern, though it should be under the authority of White people, brings a comfort for Black people. They receive the treatment, because they believe that this is what they both deserve as free Blacks, The Black people who get a freedom, but are still limited by several law is clearly seen in the novel by Ernest J. Gaines entitled A Lesson Before Dying. The law will be established in the term of public facilities, religious place, education, and civil rights. The Black Americans are dominated and discriminated within those terms of law. By this, the hegemony of White Americans is done within two phases: Phase of Domination and Phase of Directing.

\section{Phase of Domination}

Domination is understood as a condition which is suffered by a social group when it depends on a social relationship that other social group dominates it (Schuppert, 2014:29). It means that domination is about being structured. In this field, school, mass media and state institutions are common domination performed by apparatus state. The apparatus state plays an important role in a domination of a social group, because state is an apparatus of domination. As Evans. Ruschemeyer and Skocpol (1985:338) say that the apparatus state is very powerful role and have a strong interest in domination. The apparatus state then includes the ideology to a dominated social group, in which it is done to be a legal norm that is acceded by dominated social group. By this view, it can be claimed that domination is the first point in the process of hegemony.

\section{Phase of Directing}

In the case of directing, society should be submissive to the dominating social group. It is due to a fact that a state compels its ideology to society through persuasive power. Persuasive power (persuasion of power) is defined as persuading subordinate classes to accept moral, political and cultural values belong to dominant class as natural order (Jackson, 1987:53). The persuasive power can be identified through mass media, education and religion that are intentionally dominated by a state. A state then implements the awareness of society, in which the awareness unconsciously supports the power of a state.

Therefore, the first phase: phase of domination is used for the first problem of the study and the phase of directing is used for the second problem of the study. It is due to the reason that White Americans in the novel firstly dominate the law in some aspects of life and finally enable them to direct Black Americans involve their ideology into a discourse that White is the dominant and a supreme social group in which Black Americans should respect and admit White domination.

Based on these stages, Gramsci tries to provide an overview of the implementation of hegemony through two cases: moral leadership and intellectual leadership. According to Hardiman ed (2010:176), moral and intellectual leadership are mentioned as a leadership over other social groups. Moral and intellectual leadership is influential in producing a support and a consensus on dominated social group. He adds that a group can be said performing hegemony over the 
other groups for the group has an effect that encourages the emergence of agreement (consensus) of these groups. After a dominant social group obtains a consensus, a dominated social group can be argued accepting the domination of dominant social group.

\section{DISCUSSION}

\section{The Acceptance of Black Americans over The Treatment of White Americans}

The acceptance of Black Americans over the treatment of White Americans will mean a process of hegemony in the first stage: domination. Domination is an exercise of power over other social groups (Bove and Kaplan, 1997:15). It is also a condition which is suffered by a social group when it depends on a social relation that other social group dominates it. The domination is performed by the apparatus state, and they dominate school, mass media and state institutions to get an acceptance of the dominated social group (Law, 2011:105). The acceptance of Black Americans can be a cause of accepting and admitting the domination of White Americans in the Southern. The Black Americans are firstly given an opportunity to live like others. The Whites give them school, profession, and religious institution that are evidently used to get an admission and an acceptance of Black Americans over the Whites domination.

The separation of places as public facilities which appears in the Southern American, especially in Bayonne as narrated in the novel, shows a social problems over the population of Blacks and Whites in Southern America. Ernest J. Gaines as the writer of the novel narrates and describes the condition and situation of social and geographical portrait in his novel A Lesson Before Dying. In the term of separation, the separation does not only appear in the case of churches and theaters, but also educational institutions.

There were two elementary schools uptown, one Catholic, one public, for Whites; and the same back of town for colored. (Gaines 21)

The above quote explains about the separation of Whites and Blacks school. The school is an elementary school, and it is divided into two kinds of elementary schools: Catholic elementary school and public elementary school. These schools belong to
Whites. For Black schools, the schools are also categorized into Catholic and public elementary school, but those schools locates in the back of town, Bayonne.

In the style of authorship and narration in this novel, the author describes more about the setting of places with a prologue, and the prologue is expressed by the author in the novel A Lesson Before Dying. Ernest J. Gaines completely describes about geography and social conditions in the Southern America. In the beginning of his narration of the novel, he says plainly about the condition Bayonne as a small town in the novel. In the town of Bayonne, there is a separation which is performed by the honored people: Whites. The separation does not only exist in term of places of worship and theater, but also in education. In accordance with the above quote, educational institutions for Black people is located behind the town of Bayonne.

The description of the Bayonne which is described by Grant Wiggins as the main character, is an illustration which explains that Bayonne is not only seen as a small town that can be said having an adequate and sufficient public facilities, but Bayonne is no more an area in the Southern America which also has a portrait of the life of bordered society.

Bayonne's major industries were a cement plant, a sawmill, and a slaughterhouse, mostly for hogs. (Gaines 21)

Along with the stories in this novel, the acceptance of Blacks to the domination of Whites can be identified by the expression and narration of the author. Expression and narration could not be separated from the expression of Grant Wiggins as the first main character and his description of life in the Southern. As in the novel, Grant Wiggins is an elementary school teacher for Blacks. The school building which is taken to be a place of Black children is a church which is located at the quarter nearby the cotton plantation.

My classroom was the church. My classes ranged from primer to sixth grade, my pupils from six years old to thirteen and fourteen. My desk was a table, used as a collection table by the church on Sundays, and also used for the service of the Holy Sacrament on the fourth Sunday of each month. (Gaines 29) 
In the expression, Grant Wiggins illustrates some of the classes in the church. The classes consist of first to six grade of elementary school. The classes are full of children with a range of 6 years to 13 and 14 years old. In the classroom, benches which are used are the tables used in the church in every Sunday, and also used as a facility of the Holy Sacrament which is held on the fourth Sunday of each month. The church used as a place where Black children study, is a Black church that is regularly exploited as facility of Black religious activity.

My students' desks were the benches upon which their parents and grandparents sat during church meeting. (Gaines 29)

The acceptance of Blacks over the domination of Whites may also be seen from how Whites easily fit into the social life of Blacks in which Blacks then accept it as a necessity and inevitability. The acceptance over the domination of Whites is not only available in one aspect of life. However, it can be some aspects of live dominated by Whites. Domination demonstrates the leadership of Whites. That is the portrait of Whites domination described by Grant Wiggins in his depiction of the Black church school. It indicates the existence of Whites hegemony. Hegemony is the way of the dominant social group to obtain a power and to hold and maintain a control of the subordinate social group. To gain a power and hold a control, the dominant social group creates and spreads their ideas through educational, religious and social institutions.

The Blacks do not only have to comply with and acknowledge the domination of Whites who have a high position, but also those Whites who are under the control of other Whites must be obeyed. Just as Paul who is known as an official guard in the police department in Bayonne. Through his conversation with the guard, Mr. Paul, Grant Wiggins has proven the existence of an obligation to honor and respect the existence of Whites as the holders of power and control in the Southern. By showing respect, Grant Wiggins as a Black man then receives any form of decision and treatment performed by Whites against him and other Blacks.
"Paul's not here today?" I asked.

"Mr. Paul's got other duties," the deputy said.

He looked at me as if to remind me that I was supposed to say Mister before a White man's name. He stood there eyeing me until he felt that I understood. (Gaines 154-155)

Paul is a guard in a prison in Bayonne. $\mathrm{He}$ is also a White man. However, he is different than other Whites, especially who work as guard prisoners. He is a best friend for Grant Wiggins since Grant Wiggins visited detention Jefferson at the first time. Jefferson is a Black man who is accused of being involved in the case of theft and a murder in a store which is owned by a White man. Although he is a best friend for Grant Wiggins, but he remains a White man who must be obeyed and respected by Blacks. According to the citation above, Grant Wiggins firstly mentions the name of Paul by not adding a nickname at the beginning of Paul's name. After another deputy who answers Grant Wiggins' question, Grant Wiggins realizes that he has to add a title in each call Whites name. It means, although Grant Wiggins recognizes a figure of Paul who is friendly, he must still respect him as a person who deserves to be honored: the Whites.

The Whites seem to still insist on striving for their domination into Blacks' life in the Southern. They dominate and begin creating and giving some concessions to Blacks that will make them accept anything that is created and governed by the Whites. The acceptance of Blacks is also seen when Grant Wiggins visits the house of Henri Pichot to know and ensure Sheriff Guidry's decision for visiting one of Black men who is imprisoned in the Southern prison. His name is Jefferson. Grant Wiggins intends to teach the knowledge of an identity of Jefferson which involves in the theft and murder in a store. Therefore, he visit Henri Pichot's house for once to ensure whether Sheriff Guidry allows him to visit and teach Jefferson or not.

In the term of Whites domination over the Blacks life in the Southern America, the Whites domination is successful through the help of some White characters that dominate the Blacks life. Henri Pichot and Sheriff Guidry are the manifestation of apparatus states. They perform domination to Grant Wiggins and his closed Blacks. Henri Pichot has already allowed Grant Wiggins to visit his residence, 
although his visit remains to inappropriate treatment for Grant Wiggins that he has to pass over the back door to come into Henri Pichot's house. Visiting White's residence and meeting the Whites are the laws containing concession which have been decided by the Whites for the Blacks in the Southern. Besides, Sheriff Guidry is also exemplified as a manifestation of apparatus state. Sheriff Guidry has already given Grant Wiggins an allowance and a concession to visit one of Black American prisoners named Jefferson, although it also remains a restriction that he has to obey and perform when visiting Jefferson

Relevance to the theory, hegemony can be understood as Domination, influence, or authority over another, especially by one political group over a society or by one nation over others. Gramsci defines hegemony as the ability of the dominant social group in gaining and maintaining their power in society. As Femia in McCormack's book, mentions that hegemony can be obtained through internal and external control. The internal control is known as intellectual and moral leadership, while the external control is known as domination (2012:32).

As to internal control, the dominant social group does not need to force the subordinate social group to agree with their ideas. It is probably due to a reason that the dominant social group is politically dominant. In this case, the dominant social group uses a media to create their images in society, especially the subordinate social group. It is proposed to make the subordinate social group believes that the dominant social groups are intellectual people who have a high moral. Therefore, the subordinate social group believes that the ideas that come from the dominant social group are actually good for them.

\section{The Effect of White Americans Treatment towards Black Americans}

Along with the story line in the novel, Black Americans in the Southern accept the domination of Whites, and admit their mastery in whole of their life. Of course, accepting the domination of Whites means that Blacks experience myriad of effects of Whites domination. The effect of Whites domination remind us to the second phase of hegemony: phase of directing. In the phase of directing, the Black Americans should be submissive to White domination and mastery in Blacks social life.

In this phase, the Blacks as subordinate class accept moral, political, and cultural values which the Whites utilize for their hegemony in the Southern America. The Black Americans are directed to a dominant discourse which claims that although they live in the Southern and have a concession in their life in the Southern, but they cannot do anything and state themselves truly free. It means that the Black Americans are under the command of White Americans. Therefore, the previous core problem finds that the domination of Whites Americans has touched some aspects of life include Blacks right in social life and Blacks right to get a proper and certain public facilities.

Grant Wiggins admits that the Whites' command influences to what the Blacks should do. At one time, Grant Wiggins confesses about his profession as a teacher in Black school. He admits that he is the teacher of Black school. He teaches, because the Whites command him to teach. The Whites command him to teach reading, writing, and mathematics. He argues that they, the White people never tells him of how to keep Black men from the liquor store.

\footnotetext{
"Yes, I'm the teacher," I said. "And I teach what the Whites folks around here tell me to teachreading, writing, and 'rithmetic. They never told me how to keep a Black boy out of a liquor store." (Gaines 13)
}

As above quotation explains, there can obtain a comparison between two ideas that are stated by Grant Wiggins through his statement. The comparison will be about the Whites domination's influence towards the Blacks. The sentence 'They never told me how to keep a Black boy out of a liquor store' and 'And I teach what the Whites folks around here tell me to teach - reading, writing, and 'rithmetic', indicate a clear restriction on Blacks' movement, especially Grant Wiggins. The restriction is caused of the existence of the Whites' command on Blacks. In short, the Whites do not help the Blacks whom at the time was sentenced to death due to his involvement in murder and theft. 
The domination which takes a control to the lives of Blacks becomes a problem that cannot be separated from Blacks' life. In this quote, Grant Wiggins tells that how he hates the place where he lives. He hates the place and all he wants is blurred and away from the place, Bayonne. He has revealed to her aunt that he hates teaching. However, her aunt does not listen to him. Finally, Grant Wiggins reveals that how hard he screams, his aunt will not hear it.

Furthermore, the effect of Whites domination has been truly real when the case of one of Black Americans named Jefferson has been sentenced to death due to his involvement in a theft and murder in a store. The Blacks include Grant Wiggins, Miss Emma, and Tante Lou have felt the other side of White domination which is no longer beneficial and good for them: for their lives in the Southern. There is nothing what they can do toward Jefferson's death, because the trial has decided a punishment for Jefferson. For the sake of her lovely son, Miss Emma have decided to visit Henri Pichot's house to ask permission of teaching Jefferson to be a man. Her ways of asking a permission to Whites who concern with the case of Jefferson, signifies how Blacks are submissive on White domination and command.

Miss Emma comes to meet Henri Pichot to his residence. She comes along with Tante Lou and Grant Wiggins. In her meeting with Henri Pichot, Miss Emma begs to Henri Pichot in order that he can deliver permission to Sheriff Guidry. She wants to deliver her permission to Sheriff Guidry through Henri Pichot. The permission contains about Grant Wiggins' visit to the prison to teach and sensitize Jefferson to become a man. Miss Emma does this for the sake of Jefferson before he receives his sentence in the electric chair.

The trial of Jefferson which goes fiercely is initially led by the majority of White people. The White people are divided into those who organize the run of the trial, and those who state a sentence for Jefferson. They say that a Black man should die. On the other hand, the White man set a schedule of his execution without involving a negotiation with the Jefferson's people and other Blacks.

During the trial, the jury of the trial says that Jefferson almost does not resemble a man. He says and taunts when a trial is held after the report of Jefferson's involvement in the theft and murder is reported. The jury runs the trial with his personal insult to Jefferson. He says to the audiences that what he sees is not a man, but a foolish and stupid boy. He also states that he and the other White people call them civilized man, and they have reached a capacity of being a man.

\section{"Gentlemen of the jury, look at this-this-this boy. I almost said man, but I can't say man. (Gaines 9)}

Jury continues to insult Jefferson on his physical insult. He describes his physical appearance with a bad metaphor. He makes a similarity between his flat hand and Jefferson flat face. It means that, there is nothing expression that appears on the face of Jefferson. He insults Jefferson's intelligence that a man like him cannot plan such a robbery and a murder.

The jury admits that Jefferson inherits his ancestors who were in the dark forest in Africa. Although he inherits from his ancestors, but according to the jury, Jefferson cannot plan such a big and serious action like robbery and murder that are usually done by a man. The jury says that Jefferson is a man who does things according to what is commanded to him. What is ordered and commanded can include working in the fields and cotton plantations such as holding the plow, binding cotton, digging the trenches, chopping the woods, and picking the corns.

Theoretically, by external control, Gramsci states that the dominant social group needs to give influence on the behaviour and choice of the subordinate social group. The external control is applied when the dominant social group feels that the spontaneous consent has failed. In order to keep their positions in society, the dominant social group establishes sanctions or punishments to discipline the people of subordinate social group who disobey their rules. The punishment is done by the coercive help of the state which can include the police force and the army.

The domination of White Americans as seen in the novel A Lesson Before Dying has reached a legal status on the population of Black Americans. This phenomenon has been 
legally mentioned as hegemony. For a reason, in the last stage of White Americans, Black Americans are treated uncomfortably. They are directed to an ideology that they just remain a small community which only has a narrow opportunity to live and claim for their rights as nation in the Southern America. The effect of White Americans treatment is clearly seen by the incoming problem of one of Black Americans: Jefferson. The effect has been experienced by Black Americans, and it is also felt by Grant Wiggins as the main character that plays an important role in the story and in the case of Jefferson.

Once, hegemony is a kind of strategy to hold control of people or a group of people. In a social life, the practice of hegemony is usually done by a group of people who have authority in society. This kind of people is called the dominant social group. In the process of hegemony, the subordinate social group puts its trust on the dominant social group. Through this, it indirectly portrays a domination of dominant group in whole aspects of life. The dominant social group freely dominates the other social group. The subordinate social group may feel comfortable in the first phase of dominant group's domination, but the subordinate social group should have meet an effect after admitting the domination of dominant social group over their lives. The effect can be understood as a form of submission toward the dominant social group; a submission to any command and decision of the dominant social group. Thus, the dominant social group can be said successful in reaching and maintaining the domination over the subordinate social group.

\section{CONCLUSION}

A Lesson Before Dying is about the portrait of White and Black Americans in the Southern America. The Black and White Americans are the Southerners as narrated in the novel. The Black Americans are the free Blacks. Free Blacks are said as Blacks who have legal status and not being as slaves. The free Blacks live in the Southern, and they have few of restrictions that must be obeyed within their lives in the Southern. The restrictions are made by the Whites. The writer of the thesis argues that the restrictions given to the Blacks seem to be a discrimination. From this view, Whites can be said dominating the Blacks lives in the Southern. The domination itself signifies the discourse of hegemony. Therefore, the writer assumes that the portrait of Black and White relation in the Southern as narrated in the novel conceives the hegemonic discrimination. 


\section{REFERENCE}

Abrams, Dennis. (2010). Ernest J. Gaines. New York: Chelsea House

Barker, Chris., and Jane, Emma A. (2016). Cultural Studies: Theory and Practice. London: SAGE Publications Ltd

Budiman, Hikmat. (2002). Lubang Hitam Kebudayaan. Yogyakarta: Kanisius

Eriyanto. (2001). Analisis Wacana: Pengantar Analisis Teks Media. Yogyakarta: LKiS

Evans, Peter B. Reuschemeyer, Dietrich. and Skocpol, Theda. (1985). Bringing The State Back In. United Kingdom: Cambridge University Press

Freeman, Michael ed. (2011). Children's Rights: Progress and Perspectives. Boston: Martinus NIJHOFF Publishers

Griffin, Larry J., and Hargis, Peggy G. (2012). The New Encyclopedia of Southern Culture: Volume 20: Social Class. United States of America: The University of North Carolina

Hardiman, F. Budi ed. (2010). Ruang Publik: Melacak "Partisipasi Demokratis dari Polis sampai Cyberspace". Yogyakarta: Kanisius

Hatt, Christine. (2007). Slavery from Africa to The Americas: Documenting The Past. London: Evans Brothers Limited

Jackson, Peter. (1987). Race \& Racism: Essay in Social Geography. London: Allen \& Unwin

Jackson, Ronald L., and Hogg, Michael A. (2010). Encyclopedia of Identity: Volume II. United States of America: SAGE Publications, Inc

Law, Alex. (2011). Key Concepts in Classical Social Theory. London: SAGE

McCormack, Mark. (2012). The Declining Significance of Homophobia: How Teenage Boys are Redefining Masculinity and Heterosexuality. United States of America: Oxford University Press

Patria, Nezar and Arief, Andi. (1999). Antonio Gramsci Negara \& Hegemoni. Yogyakarta: Pustaka Pelajar

Plehwe, Dieter, Walpen, Bernhard J. A and Neunhöffer, Gisela ed. (1006). Neoliberal Hegemony: A Global Critique. New York: Routledge

Raco, J.R. (2010). Metode Penelitian Kualitatif, Jenis, Karakteristik, dan Keunggulannya: Jakarta: Grasindo, 2010

Ratna, Nyoman Kutha. (2005). Sastra dan Cultural Studies: Representasi Fiksi dan Fakta. Yogyakarta: Pustaka Pelajar

Saifuddin, A.F. (2006). Antropologi Kontemporer; Suatu Pengantar Kritis Mengenai Paradigma. Jakarta: Prenada Media Group

Schuppert, Fabian. (2014). Freedom, Recognition and Non-Domination: A Republican Theory of (Global) Justice. London: Springer, 
LiNGUA Vol. 13, No. 1, Juni 2018 •ISSN 1693-4725 • e-ISSN 2442-3823

Simon, Roger. (2001). Gramsci's Political Thought: An Introduction. London: The Electric Book Company Ltd. 